\title{
Effect of dietary antioxidant supplementation on reproductive characteristics of male broiler breeders during the post-peak production phase
}

\section{Efeito da suplementação dietética de antioxidantes sobre características reprodutivas de machos reprodutores de frangos de corte na fase pós pico de produção}

\author{
Gustavo Eugênio Triques ${ }^{1}$; Joice Meri Schmidt ${ }^{1}$; Camila Souza Oro ${ }^{2}$; \\ Heloísa Fialkowski Bordignon²; Daiane Güillich Donin³; \\ Jovanir Inês Müller Fernandes ${ }^{3 *}$
}

\begin{abstract}
Because of their membrane constitution, sperm cells of male broiler breeders are prone to lipid peroxidation, which affects their fertilizing capacity. The aim of the present study was to evaluate the effects of antioxidant diet supplementation on the reproductive characteristics of 12 male broiler breeders $(\mathrm{Cobb})$ older than 50 weeks. The roosters were randomly distributed in a completely randomized experimental design with two treatments (treatment 1: commercial feed; treatment 2: commercial feed supplemented with canthaxanthin, lycopene, and vitamin C) and 6 replicates. Semen samples were collected by abdominal massage, and then underwent evaluation of semen volume, sperm concentration, motility, vigor, and morphology. Morphometric analyses of testes, combs, and dewlaps were performed at 68 weeks. Testes samples were collected for morphometric analysis of seminiferous tubules and analysis of cellular proliferation in the germinal epithelium by using immunohistochemical staining with anti-proliferating cell nuclear antigen (anti-PCNA) antibodies. Statistical data analysis was performed using the SAS software (SAS, 2002). No significant effects of antioxidant supplementation were observed on semen characteristics $(p>0.05)$. A significant positive effect of the antioxidant blend was observed on the percentage of normal sperm, dewlap weight and width, and testes weight and length $(p<0.05)$. PCNA-positive cell counts and morphometry of the seminiferous tubules were not affected by the treatment. Dietary antioxidant supplementation may represent a nutritional tool to increase fertility in male broiler breeder flocks during the post-peak production phase.
\end{abstract}

Key words: Canthaxanthin. Roosters. Lycopene. Lipid peroxidation. Vitamin C.

\section{Resumo}

Os espermatozoides de machos reprodutores de frango de corte são células propensas a peroxidação lipídica, dada à constituição biológica de sua membrana, influenciando a capacidade fertilizante do macho. O objetivo deste trabalho foi avaliar o efeito da suplementação dietética de antioxidantes

\footnotetext{
${ }^{1}$ Discentes do Curso de Mestrado do Programa de Pós-Graduação em Ciência Animal, Universidade Federal do Paraná, UFPR, Palotina, PR, Brasil. E-mail: gustavo.triques@jbsfoods.com.br; joice.214@gmail.com

2 Discentes do Curso de Graduação em Medicina Veterinária, UFPR, Palotina, PR, Brasil. E-mail: camilaorovet@gmail.com; heloisa.veterinaria@gmail.com

3 Docentes do Departamento de Zootecnia, Programa de Pós-Graduação em Ciência Animal, UFPR, Palotina, PR, Brasil. E-mail: daidonin@yahoo.com.br; jimfernandes@ufpr.br

* Author for correspondence
} 
sobre características reprodutivas de machos reprodutores de frangos de corte com idade superior a 50 semanas. Foram utilizados 12 galos Cobb de 50 semanas de idade distribuídos aleatoriamente em um delineamento inteiramente casualizado com 2 tratamentos (tratamento 1: ração comercial; tratamento 2: ração comercial suplementada de cantaxantina, licopeno e vitamina C) e 6 repetições. Amostras de sêmen foram coletadas pelo método de massagem abdominal e submetidas à avaliação do volume seminal, concentração, motilidade, vigor e morfologia espermática. Às 68 semanas de idade, amostras de testículo foram coletadas para determinação da morfometria tubular dos testículos e para análise da proliferação celular no epitélio germinativo através de imunohistoquímica anti-PCNA. A morfometria de testículos, cristas e barbelas foram analisadas nas 68 semanas de idade. Os dados foram submetidos à análise estatística utilizando-se o software SAS (SAS, 2002). Não foram observadas diferenças significativas $(p>0,05)$ com a adição dos antioxidantes sobre as características seminais. Houve efeito positivo $(p<0,05)$ do blend de antioxidantes no percentual de espermatozoides normais, no peso e largura das barbelas e no peso e comprimento dos testículos. A contagem de células PCNA-positivas e as medidas morfométrias dos túbulos seminíferos dos testículos dos galos não sofreram influência do tratamento. A adição de antioxidantes na dieta de machos reprodutores de frango de corte na fase póspico pode ser uma ferramenta nutricional para melhorar o índice de fertilidade dos lotes de matrizes de frangos de corte.

Palavras-chave: Cantaxantina. Galos. Licopeno. Peroxidação lipídica. Vitamina C.

\section{Introdução}

In broiler breeder flocks, males are considered more important than females because they can produce larger progenies per year than that by females (HAMMERSTEDT, 1999). Although only $10 \%$ of the broilers in breeder flocks are males, they contribute to $50 \%$ of the genetic information. Breeder males are essential for the fertility of breeder flocks, and information on nutritional factors that affect their reproductive performance are not in agreement with their success of reproduction.

Although the use of specific diets for males has been confirmed to improve fertility and egg hatching, some poultry producers are still against their use. A linear negative correlation between body weight and infertility was observed in flocks of males with weights between 4.5 and $5.9 \mathrm{~kg}$ (i.e., the male fertility percentage decreased with increase in body weight) (FRAGOSO et al., 2013). Consequently, this correlation is directly affected by male age.

Changes in secondary sex characteristics with increasing male age are also common, and according changes in the amount of sperm ejaculated, semen volume, sperm motility, and viability, as well as changes leading to a decreased fertilizing capacity, which may also affect sperm preservation during storage (IAFFALDANO; MELUZZI, 2003).

These changes, which are common to all species, represent the failure of the antioxidant system. Weir and Robaire (2007) compared the activity of antioxidant enzymes in sperm cells during sperm maturation in young and old rats. In their study, they observed a decreased antioxidant capacity with animal aging. Peroxide formation, and consequently lipid peroxidation of sperm, therefore, may have a negative effect on fertility rates, since peroxidized sperm have decreased fluidity and fertilizing capacity (AITKEN, 1995).

The failure or incapacity of antioxidant systems in protecting the sperm is related to the sperm lipid composition. Sperm membranes are mainly constituted of phospholipids that contain large quantities of polyunsaturated fatty acids (MARTIN-RILLO et al., 1996), and therefore, are more susceptible to oxidative damages, called lipid peroxidation, and may cause cell dysfunction and death (SURAI, 2002).

Oxidative stress may be reduced by antioxidant supplementation of broiler breeder diets (AITKEN, 1995; SURAI, 2002; RUTZ et al., 2007; HAMMADEH et al., 2009; KIM et al., 2010). 
Vitamins $\mathrm{C}$ and $\mathrm{E}$ and carotenoids are some of the most studied antioxidant dietary supplements (MAKKER et al., 2009; BANSAL; BILASPURI, 2010).

Lycopene and canthaxanthin are carotenoids noted for their high oxygen sequestration capacity (FONTANA et al., 2000). Ferreira (2010) observed changes associated with the increase of sperm motility and concentration and decrease in sperm morphology in male breeders fed diets supplemented with canthaxanthin. Mangiagalli et al. (2010) tested the effect of water supplemented with lycopene and noted that male broiler breeders that received lycopene showed higher sperm production and viability.

Vitamin $\mathrm{C}$ is characterized by its ability to act as reducing agent, donating electrons, and quickly reacting with free radicals. In addition, it acts synergistically with vitamin E, regenerating it in biological systems such as the seminal plasma.

As previously mentioned, the use of specific diets for male boilers is recent and not a common practice. Most of the studies on dietary antioxidants, therefore, have been performed using mammals. Yousef et al. (2003) observed that supplementation with vitamin $\mathrm{C}$ or $\mathrm{E}$, and their combination had positive effects on semen characteristics and resulted in decreased oxidative stress in rabbit semen. Similar results were noted by Mishra and Acharya (2004) for vitamin C supplementation. Bansal and Bilaspuri (2010) observed higher sperm motility, viability, and lower rate of lipid peroxidation in the sperm of bulls fed diets supplemented with vitamin E.

The present study aimed to evaluate the effects of antioxidant diet supplementation on the reproductive parameters of male broiler breeders during the post-peak production phase.

\section{Material and Methods}

The experiments were performed at the aviary of the Federal University of Paraná (Universidade
Federal do Paraná - UFPR), Palotina Campus. For all animal raising and biological material collection, procedures were approved by the Ethics Committee on Animal Use in Research (no. 29/2012).

Twelve Cobb roosters aged 50 weeks were collected from the same breeder flock of a local farm. Sexually mature roosters (color of face and comb, and growth of comb and dewlap) with uniform body weight $(4.5 \mathrm{~kg} \pm 2 \%)$ and no physical abnormalities were selected. We placed one breeder rooster per cage; the cages were distributed randomly between treatments by using a completely randomized experimental design, with two treatments and 6 replicates.

A corn and soy meal-based diet, formulated according to the nutritional demands of postpeak production roosters (COBB VANTRESS, 2013) was used. The following treatments were used: treatment 1-commercial feed; and treatment 2-commercial feed $+8 \mathrm{ppm}$ canthaxanthin (Carophyll Red; DSM Nutritional Products) + Lycopene 40 ppm (Lycopene 10\%; Roche Vitamins) + 150 ppm Vitamin C (Rovimix C-EC 97.5\%; DSM Nutritional Products). During the experiment, food was supplied daily (8 AM) in the amount recommended in the Cobb lineage manual $(150 \mathrm{~g} /$ rooster/day). Room temperature was maintained at a constant $23^{\circ} \mathrm{C} \pm 2{ }^{\circ} \mathrm{C}$ by using exhausts and an air conditioning system. Starting from the second week of housing, semen collection by stimulation of roosters was performed daily, in order for the roosters to become used to the procedure. Stimulation was performed through abdominal massage according to Burrows and Quinn (1937) and was always performed by the same person. Three semen collections were performed during the experimental period.

Semen was collected using an insulin syringe, and the volume was measured by direct reading. Sperm concentration was measured in a 1:200 semen dilution according to Brillard (1992). Semen was diluted in buffered formalin, composed of 
$29 \%$ sodium citrate and $37 \%$ formaldehyde, and sperm were counted in five fields on each side of a Neubauer chamber. The average was calculated, multiplied by the dilution factor $(10,000)$, and expressed as number of sperm cells $/ \mathrm{mm}^{3}$. The total number of cells was calculated by multiplying the concentration and ejaculated semen volume. Sperm motility and vigor were estimated by the percentage and type of movement of sperm cells, under a microscope at $400 \times$ magnification.

Sperm morphology was analyzed by measuring the occurrence of normal and abnormal sperm, which present problems at the head, mid-piece, or tail. Semen smears were stained with bromophenol blue. A drop of semen was added to a drop of blue bromophenol, homogenized, and incubated for 30 s. Smears were prepared using a drop of this mix, and the glass slides were allowed to dry at ambient temperature prior to analysis. The semen and dye were kept at the same temperature $\left(37^{\circ} \mathrm{C}\right)$. A total of 200 sperm cells were counted for each sample by using a light microscope equipped with an immersion lens, at $100 \times$ magnification.

On the last week of the experiment, i.e., at 68 weeks, comb thickness and weight and dewlap length, width, and weight, were measured for all roosters. The roosters were weighed and killed. Animal killing was performed according to the guidelines of the National Council for the Control of Animal Experimentation (Conselho Nacional de Controle de Experimentação Animal - CONCEA). The animals were physically restrained, followed by insertion of a catheter (n. 22) into the femoral vein to deliver a bolus injection of propofol (Propovan $10 \mathrm{mg} / \mathrm{mL}$, Cristália Laboratory) until loss of consciousness was confirmed. Potassium chloride was then immediately administered in the same manner (19.1\% potassium chloride, Isofarma Laboratory) until death was confirmed.

Testes were measured and weighed. Crosssectional pieces of testes were dipped into buffered formalin, fixed in paraffin, and cut into semi-seriate 5 - $\mu \mathrm{m}$-thick sections. The testes pieces were fixed in paraffin and oriented such that the seminiferous tubules in the sections can be observed by staining with hematoxylin and eosin. For morphometric analyses, images were captured using a light microscope (Olympus BX 50) and analyzed using a computerized image analysis system (ImagePro-Plus 5.2, Média Cibernética). Interstitial spaces, diameter, and epithelium height of seminiferous tubules were measured in ten areas for each testis.

Cell proliferation in the germinal epithelium was analyzed according to Gosselin et al. (1986), with modifications. The 5 - $\mu$ m-thick testes sections were placed on glass slides and prepared for immunohistochemical detection of mitotic cells by using a monoclonal anti-proliferating cell nuclear antigen (anti-PCNA) antibody (Santa Cruz $\left.{ }^{\circledR}\right)$. Ten images were captured from each slide and PCNA positive and negative cells were quantified (Figure 1).

Preliminary data analyses were performed to check for outliers and to ensure no violation of the assumptions of normality (Cramer Von Mises test) and homogeneity of variance (Brown-Forsythe test). The data were then subjected to variance analysis by using the GLM procedure of the SAS software (SAS, 2002), at $p<0.05$. Average of PCNA-positive cells in the seminiferous tubule epithelium was analyzed considering a Poisson distribution with log link function, by using the GENMOD procedure of SAS. 
Figure 1. Histological section showing the germinal epithelium (ge) and lumen (lu) of seminiferous tubules of roosters receiving diet supplemented with an antioxidant blend. A) anti-proliferating cell nuclear antigen (anti-PCNA) positive nuclei (arrows) stained with DAB (3,3'-Diaminobenzidine) in brown, and anti-PCNA negative nuclei counterstained with hematoxylin. B) Negative control (neg) with omission of the primary antibody. Bar: $30 \mu \mathrm{m}$.

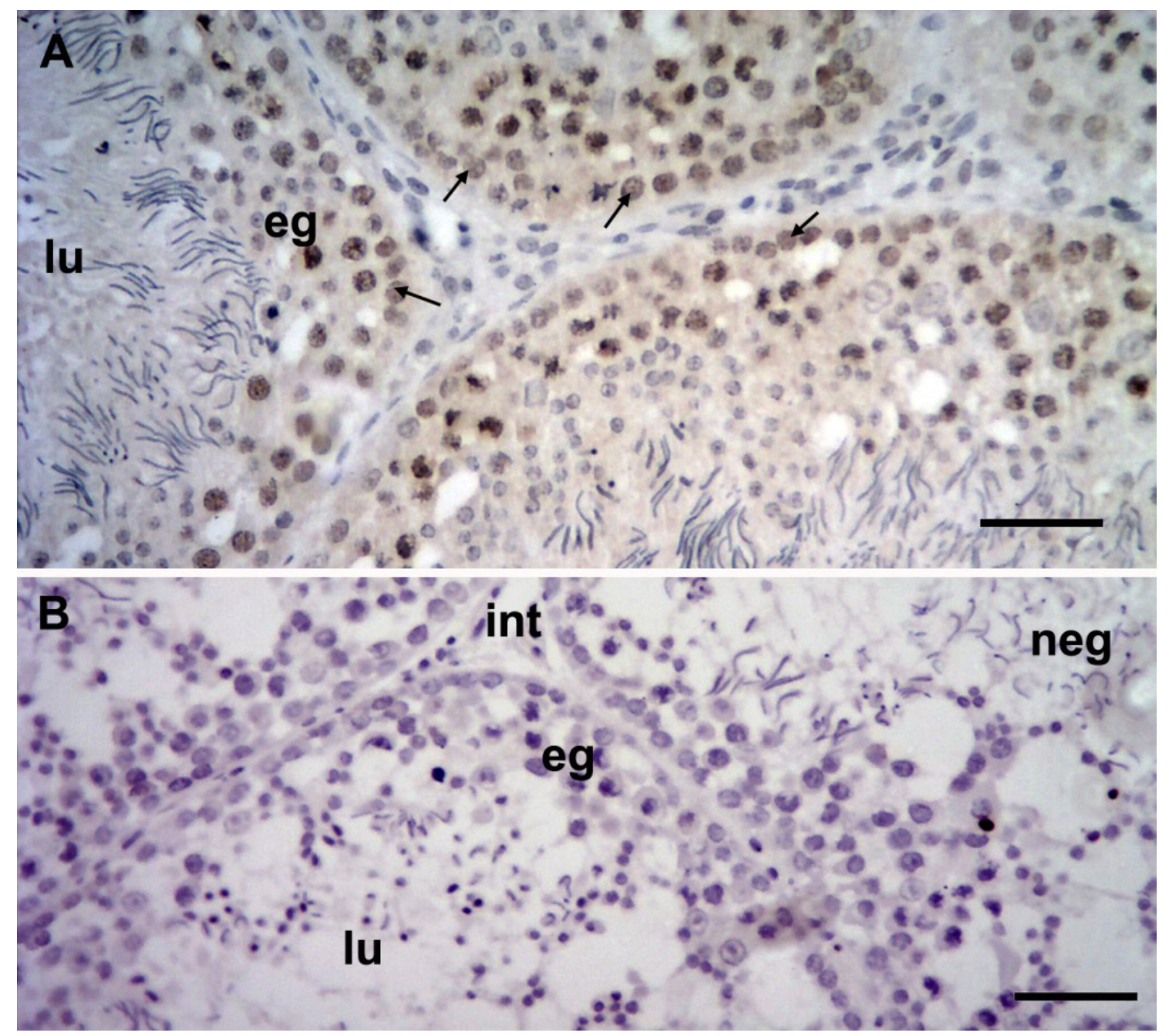

\section{Results and Discussion}

No effects of diet supplementation with the antioxidant blend were observed on semen volume and sperm motility, as well as vigor and concentration of roosters during the post-peak production phase (Table 1). Some physical factors, such as increase in body weight and breast size, limb traumas and muscle pain, and decrease in frequency of copulation, may be related to decreased fertility in older flocks and may have a larger effect on infertility than on oxidative stress (FRAGOSO et al., 2013). Akhlaghi et al. (2014) also observed no effects of antioxidant supplementation on sperm concentration and viability.

In addition, sperm quality is quantified based on subjective factors such as visual estimations. Previous studies have reported a variation of these estimations from $30 \%$ to up to $60 \%$, because of human limitations in quantifying the different sperm samples from subpopulations (VERSTEGEN et al., 2002). In order to decrease this subjectivity, automated computerized semen analysis systems have been tested with the goal of obtaining further data that are accurate. However, in contrast with 
the data from other species, there are still only few studies of rooster semen; thus, there is still no reliable parameters for analysis (LUCASZEWICZ et al., 2008; ARRUDA et al., 2011).

Table 1. Seminal characteristics of roosters at the age of 50 weeks, supplemented or not with antioxidant blend.

\begin{tabular}{lcccc}
\hline & $\begin{array}{c}\text { Volume, } \\
\mathrm{ml}\end{array}$ & $\begin{array}{c}\text { Motility, } \\
\%\end{array}$ & Vigor (score) & $\begin{array}{c}\text { Sperm concentration } \\
\text { billion } / \mathrm{ml}\end{array}$ \\
\hline Control & 0.25 & 86.67 & 4.06 & 3.393 \\
Antioxidant blend & 0.24 & 87.39 & 4.44 & 4.693 \\
$\mathrm{CV}, \%$ & 62.47 & 5.30 & 12.28 & 92.00 \\
P Value & 0.8789 & 0.7578 & 0.0723 & 0.2988 \\
\hline
\end{tabular}

On the other hand, the semen of old roosters has been observed to have higher degree of chromatin changes than that of young roosters, which may decrease their fertility, even in the absence of changes in the semen physical characteristics (RODRIGUES et al., 2009). Bergstein et al. (2014) reported that although sperm motility and membrane integrity tests are important, these may not reveal relevant sperm lesions. This shows the need for broadening the methods of evaluation of rooster semen characteristics.

In this study, roosters receiving diet with antioxidant blend supplementation presented higher percentage of normal sperm than that in the control group $(p<0.05$; Table 2$)$.

Table 2. Morphology of spermatozoa (\%) of roosters over 50 weeks of age supplemented or not with antioxidant blend.

\begin{tabular}{lcccc}
\hline & Normal & Head & Tail & Middle piece \\
\hline Control & $75.69^{\mathrm{b}}$ & 10.5 & 11.06 & 2.75 \\
Antioxidant blend & $82.33^{\mathrm{a}}$ & 7.92 & 8.17 & 1.58 \\
$\mathrm{CV}, \%$ & 5.22 & 25.39 & 28.82 & 60.92 \\
P Value & 0.0366 & 0.0849 & 0.1829 & 0.8366 \\
\hline
\end{tabular}

The observed percentages of normal sperm for both the control and antioxidant supplementation treatment were close to those reported by Łukaszewicz et al. (2008). Similar results were also reported by Ferreira (2010) who added 6 ppm of canthaxanthin to the diet of 40-59-week-old roosters and observed decreased changes in the sperm morphology; this effect was attributed to the antioxidant supplementation. This is in contrast with the result of Rodenas et al. (2005) who observed no significant effect of different rooster diets on sperm morphology. Lycopene supplementation of rooster diets has been previously observed to have both in vivo and in vitro positive effects on semen viability (MANGIAGALLI et al., 2010).

Because abnormal sperm may have compromised motility or even survival, high flock fertility is ensured when the percentage of normal sperm is the highest (BONGALHARDO et al., 1994; MACIEL, 2006).

The higher percentage of abnormal sperm in the control group when compared to the treatment group may be attributed to oxidative stress, which 
could be because of the relationship between age and the high quantity of polyunsaturated fatty acids in the sperm composition.
Roosters receiving the diet supplemented with the antioxidant blend presented significantly higher testis weight and length than those of the control group $(p<0.05$; Table 3$)$.

Table 3. Biometric indices of dewlap (weight, length and width), comb (thickness and weight) and tests (weight, length and width) of roosters over 50 weeks of age, supplemented or not with antioxidant blend.

\begin{tabular}{lcccccccc}
\hline & \multicolumn{3}{c}{ Dewlap } & \multicolumn{3}{c}{ Comb } & \multicolumn{3}{c}{ Tests } \\
\cline { 2 - 8 } & $\begin{array}{c}\text { Weight } \\
(\mathrm{g})\end{array}$ & $\begin{array}{c}\text { Length } \\
(\mathrm{cm})\end{array}$ & $\begin{array}{c}\text { Width } \\
(\mathrm{cm})\end{array}$ & $\begin{array}{c}\text { Thickness } \\
(\mathrm{mm})\end{array}$ & $\begin{array}{c}\text { Weight } \\
(\mathrm{g})\end{array}$ & $\begin{array}{c}\text { Weight } \\
(\mathrm{g})\end{array}$ & $\begin{array}{c}\text { Length } \\
(\mathrm{cm})\end{array}$ & $\begin{array}{c}\text { Width } \\
(\mathrm{cm})\end{array}$ \\
\hline Control & $13.66^{\mathrm{b}}$ & 6.50 & $5.79^{\mathrm{b}}$ & 47.32 & 12.18 & $19.09^{\mathrm{b}}$ & $3.73^{\mathrm{b}}$ & 2.30 \\
Antioxidant blend & $21.18^{\mathrm{a}}$ & 7.33 & $7.18^{\mathrm{a}}$ & 66.89 & 14.33 & $32.73^{\mathrm{a}}$ & $4.66^{\mathrm{a}}$ & 2.66 \\
CV, \% & 25.52 & 11.01 & 12.78 & 28.97 & 19.75 & 23.07 & 11.36 & 14.4 \\
P Value & 0.010 & 0.274 & 0.008 & 0.359 & 0.148 & 0.001 & 0.004 & 0.097 \\
\hline
\end{tabular}

McGary et al. (2002) reported a positive correlation between testis weight and sperm production. Combs and dewlaps are also evaluated for phenotypic evaluation of the sexual condition of males and are directly associated with good sexual development in males (TYLER; GOUS, 2008).

However, although roosters receiving antioxidant diet supplementation presented high testes weights, this characteristic was not correlated with sperm production. This result is in contrast with the result of França and Russell (1998) who concluded that sperm production was directly associated with testes weight and is higher for roosters with larger testes.

Dewlap weight and width and comb weight were also significantly higher for the group receiving diet supplemented with the antioxidant blend $(p<$ 0.05; Table 3). Combs and dewlaps are widely used for the phenotypic evaluation of sexual condition of breeder males, and in some studies, these were found to be closely related to high indexes of flock fertility.

McGary et al. (2005) related secondary sexual characteristics with factors such as fertility and concluded that a positive correlation exists between testis weight and comb area, as well as between comb height and dewlap length and sperm penetration into the perivitelline membrane. Higher fertility has been reported for roosters with welldeveloped combs, since they dominate over roosters with smaller combs and present better sperm characteristics (CELEGHINI et al., 2001). Rosa et al. (2012) observed that, during the final period of rearing, adult males with whole combs presented larger testis epithelium than that in males with half comb. Further, males without comb presented the lowest area and height of seminiferous epithelium and the smallest seminiferous tubule diameter, showing a correlation between the comb and the male reproductive system.

According Akhlaghi et al. (2014), although chickens may mate with several roosters and choose males based on a combination of multiple secondary sexual characteristics, comb size and color seem to be the most important characteristics for partner choice by chickens.

The results presented in Table 3, therefore, indicate that antioxidant diet supplementation may have a positive effect on fertility rates of breeder flocks. The secondary sexual characteristics (combs and dewlaps) may be used to identify male breeders without adequate conditions for reproduction and remove them from the breeder flock, especially 
in older breeder flocks with low recommended male:female ratio.

The morphometric measurements of seminiferous tubules and PCNA-positive cell counts observed in the present study are presented in Table 4. We observed no significant effects of antioxidant diet supplementation on the morphometry of seminiferous tubules $(p>0.05)$.
PCNA is a highly sensitive method used to quantify testicular damage, including damage caused by lipid peroxidation (D'ANDREA et al., 2008). Unlike the semen volume and sperm concentration analyses, PCNA allows the evaluation of testicular condition shortly after the occurrence of damage. PCNA is a cofactor of DNA polymerase, necessary for DNA synthesis, and plays a critical role in the beginning of cell proliferation (CELIS; CELIS, 1985).

Table 4. Morphometric measures of the seminiferous tubules and counting of PCNA-positive cells from tests of roosters supplemented or not with antioxidant blend.

\begin{tabular}{lcccc}
\hline & $\begin{array}{c}\text { Interstitial space } \\
\left(\mu \mathrm{m}^{2}\right)\end{array}$ & $\begin{array}{c}\text { Diameter } \\
(\mu \mathrm{m})\end{array}$ & $\begin{array}{c}\text { Epithelium } \\
(\mu \mathrm{m})\end{array}$ & PCNA-positive cells \\
\hline Control & 131.89 & 442.60 & 116.34 & 97.1 \\
Antioxidant blend & 119.97 & 440.77 & 103.85 & 80.2 \\
CV, \% & 23.45 & 12.33 & 17.89 & 18.23 \\
P Value & 0.346 & 0.224 & 0.122 & 0.098 \\
\hline
\end{tabular}

Fragoso et al. (2013) also observed pathological changes in the testes of roosters older than 55 weeks, but found no changes in the morphometry of seminiferous tubules.

Diet supplementation with the antioxidant blend did not affect cell proliferation in testicular tissue of roosters $(p>0.05)$. PCNA is used for precocious detection of testicular damage, which did not seem to be significantly different between the treatment and control groups in the present study. Regarding tubule morphometry, roosters up to 12 weeks of age present seminiferous tubules formed by a single layer of Sertoli cells and spermatogonia, which develop into a stratified seminiferous epithelium, with marked decrease in interstitial tissue as the roosters become sexually mature (GONZÁLESMORAN et al., 2008).

The number of Sertoli cells in adult testes determines both the testes size and the daily sperm production. This is because each Sertoli cell can only sustain a fixed number of germ cells, although this number varies among species (SHARPE et al., 2003).
In mammals, only immature Sertoli cells proliferate, and the final number of Sertoli cells is determined before adulthood. However, this has not been confirmed for breeder roosters (ORTH et al., 1988).

If the proliferation mechanism of Sertoli cells is similar to that in mammals, providing antioxidant diet supplementation at the begin of rooster life rather than at the post-peak production phase may positively affect seminiferous tubule morphometry and number of germ cells, as discussed in the present study.

\section{Conclusions}

Antioxidant diet supplementation resulted in higher percentage of normal sperm cells in male broiler breeders older than 50 weeks.

Males receiving antioxidant diet supplementation presented superior biometric characteristics of comb, dewlap, and testes.

Diet supplementation with the antioxidant blend during the post-peak production phase did not affect cell proliferation in testicular tissues of roosters. 


\section{References}

AITKEN, R. J. Free radicals, lipid peroxidation and sperm function. Reproduction Fertility and Development, Clayton South, v. 7, n. 4, p. 659-668, 1995.

AKHLAGHI, A.; JAFARI AHANGARI, Y; NAVIDSHAD, B.; ANSARI PIRSARAEI, Z.; ZHANDI, M.; DELDAR, H.; REZVANI, M. R.; DADPASAND, M.; HASHEMI, S. R.; POURESLAMI, R.; PEEBLES, E. D. Improvements in semen quality, sperm fatty acids, and reproductive performance in aged Cobb 500 breeder roosters fed diets containing dried ginger rhizomes (Zingiberofficinale). Poultry Science, Champaign, v. 93, n. 5, p. 1236-1243, 2014.

ARRUDA, R. P.; CELEGHINI, E. C. C.; ALONSO, M. A.; CARVALHO, H. F.; OLIVEIRA, L. Z.; NASCIMENTO, J.; SILVA, D. F.; AFFONSO, F. J.; LEMES, K. M.; JAIMES, J. D. Métodos de avaliação da morfologia e função espermática: momento atual e desafios futuros. Revista Brasileira de Reprodução Animal, Belo Horizonte, v. 35, n. 3, p. 145-151, 2011.

BANSAL, A. K.; BILASPURI, G. S. Impacts of oxidative stress and antioxidants on semen functions. Veterinary Medicine International, Bologna, v. 2011, n. 686137, p. 1-7, 2010.

BERGSTEIN, T. G.; WEISS, R. R.; BICUDO, S. D. Técnicas de análise de sêmen. Revista Brasileira de Reprodução Animal, Belo Horizonte, v. 38, n. 4, p. 189194, 2014.

BONGALHARDO, D.; DIONELLO, N. J.; CARDELLINO, R. A.; BRACCINI NETO, J. Repetibilidade e correlações fenotípicas do caráter volume de sêmen de galos White Leghorn. Revista da Sociedade Brasileira de Zootecnia, Viçosa, MG, v. 23, n. 6, p. 1002-1007, 1994.

BRILlARD, J. P. Production de pollitos de carne por inseminación artificial. Técnicas en Avicultura, Montevideo, v. 8, n. 43, p. 1335-1339, 1992.

BURROWS, W. H.; QUINN, J. P. The collection of spermatozoa from the domestic fowl and turkey. Poultry Science, Champaign, v. 16, n. 1, p. 19-24, 1937.

CELEGHINI, E. C. C.; ALBUQUERQUE, R.; ARRUDA, R. P.; LIMA, C. G. Avaliação das características seminais de galos selecionados para a reprodução pelo desenvolvimento da crista. Brazilian Journal Veterinary Research of Animal Science, São Paulo, v. 38, n. 4, p. 177-183, 2001.

CELIS, J. E.; CELIS, A. Cell cycle-dependent variations in the distribution of the nuclear protein cyclin proliferating cell nuclear antigen in cultured cells: subdivision of S-phase. Proceedings of the National Academy of Sciences, Boston, v. 82, n. 10, p. 3262-3266, 1985.

COBB VANTRESS. Guia de manejo de matrizes COBB. Guapiaçu: Cobb Vantress Brasil, 2013. 57 p.

D’ANDREA, M. R.; LAWRENCE, D.; NAGELE, R. G.; WANG, C. Y.; DAMIANO, B. P. PCNA indexing as a preclinical biomarker for testicular toxicity. Biotechnic and Histochemistry, New York, v. 83, n. 5, p. 211-220, 2008.

FERREIRA,P.B. Cantaxantinae 25-hidroxicolecalciferol e seus efeitos sobre os aspectos reprodutivos de galos. 2010. Dissertação (Mestrado em Zootecnia) - Centro de Ciências Rurais, Universidade Federal de Santa Maria, Santa Maria.

FONTANA, J. D.; MENDES, S. V.; PERSIKE, D. S.; PERACETTA, L.; PASSOS, M. Carotenoides: cores atraentes e ação biológica. Biotecnologia, Ciência e Desenvolvimento, Brasília, v. 13, n. 1, p. 40-45, 2000.

FRAGOSO, S. J.; PIZARRO, D. M.; ABAD, M. J. C.; CASANOVAS, I. P.; RODRIGUEZ-BERTOS, A.; BARGER, K. Relationships between fertility and some parameters in male broiler breeders (body and testicular weight, histology and immunohistochemistry of testes, spermatogenesis and hormonal levels). Reproduction in Domestic Animals, London, v. 48, n. 2, p. 345-52, 2013.

FRANÇA, L. R.; RUSSELL, L. D. The testis of domestic animals. In: MARTINEZ-GARCIA, F.; REGADERA, J. (Ed.). Male reproduction; a multidisciplinary overview. Madrid: Churchill Comunication, 1998. p. 197-219.

GONZÁLES-MORAN, M. G.; GUERRA-ARAIZA, C.; CAMPOS, M. G.; CAMACHO-ARROYO, I. Histological and sex steroid hormone receptor changes in testes of immature, mature and aged chickens. Domestic Animal Endocrinology, New York, v. 35, n. 4, p. 371379, 2008.

GOSSElin, E. J.; CATE, C. C.; PetTengil, O. S.; SORENSON, G. D. Immunocytochemistry: its evaluation and criteria for its application in the study of epon-embebedded cell and tissue. American Journal of Anatomy, Philadelphia, v. 175, n. 2-3, p. 135-160, 1986.

HAMMADEH, M. E.; FILIPPOS, A.; HAMAD, M. F. Reactive oxygen species and antioxidant in seminal plasma and their impact on male fertility. International Journal of Fertility and Sterility, Tehran, v. 3, n. 3, p. 87-110, 2009.

HAMMERSTEDT, R. H. Symposium summary and challenges for the future. Poultry Science, Champaign, v. 78, n. 3, p. 459-466, 1999. 
IAFFALDANO, N.; MELUZZI, A. Effect of dialysis on quality characteristics of turkey semen during liquid storage. Theriogenology, London, v. 60, n. 3, p. 421-427, 2003.

KIM, K. S.; PAIK, I. Y.; WOO, J. H.; KANG, B. Y. The effect of training type on oxidative damage and antioxidant capacity during three-dimensional space exercise. Medical Principles and Practice, Shadadiyahv, v. 19, n. 2, p. 133-141, 2010.

ŁUKASZEWICZ, E.; JERYSZ, A.; PARTYKA, A.; SIUDZINSKA, A. Efficacy of evaluation of rooster sperm morphology using different staining methods. Veterinay Science, Basel, v. 85, n. 3, p. 583-588, 2008.

MACIEL, M. P. Características reprodutivas de galos leves e semi-pesados submetidos a diferentes foto periodos. 2006. Tese (Doutorado em Zootecnia) Universidade Federal de Lavras, Lavras.

MAKKER, K.; AGARWAL, A.; SHARMA, R. Oxidative stress and male infertility. Indian Journal of Medical Research, New Delhi, v. 129, n. 5, p. 597-603, 2009.

MANGIAGALLI, M. G.; MARTINO, P. A.; SMAJLOVIC, T.; GUIDOBONO-CAVALCHINI，L.; MARELLI, S. P. Effect of lycopene on semen quality, fertility and native immunity of broiler breeder. British Poultry Science, London, v. 51, n. 1, p. 152-157, 2010.

MARTIN-RILLO, S.; MARTINEZ, E.; GARCIAARTIGA, C.; DE-ALBA, C. Bora semen evaluation in practice. Reproduction Domestics Animal, Amsterdam, v. 31, n. 4, p. 519-526, 1996.

MCGARY, S.; BROUGHER, S.; ESTEVEZ, I.; OTTINGER, M. A. Can testosterone and corticosterone predicted the rate of display of male sexual behavior, development of secondary characters and fertility potential in primary broiler breeders? Poultry Science, Champaign, v. 46, n. 4, p. 621-625, 2005.

MCGARY, S.; ESTEVEZ, I.; BAKST, M. R. Phenotypic traits as reliable indicators of fertility in male broiler breeders. Poultry Science, Champaign, v. 81, n. 1, p. 102111, 2002.

MISHRA, M.; ACHARYA, U. R. Protective action of vitamins on the spermatogenesis in lead-treated Swiss mice. Journal of Trace Elements in Medicine and Biology, Neuherberg, v. 18, n. 2, p. 173-178, 2004.

ORTH, J. M.; GUNSALUS, G. M.; LAMPERTI, A. A. Evidence from Sertoli cell-depleted rats indicates that spermatid numbers in adults depends on numbers of Sertoli cells produced during perinatal development. Endocrinology, Boston, v. 122, n. 3, p. 787-794, 1988.

RODENAS, C. E. O.; MURGAS, L. D. S.; MACIEL, M. P.; FERRAZ, J. M.; RIBEIRO, M. C.; BERTECHINI, A.
G.; FREITAS, R. T. F.; FIALHO, E. T. Características seminais de galos alimentados com rações suplementadas com diferentes óleos e níveis de vitamina E. Ciência e Agrotecnologia, Lavras, v. 29, n. 1, p. 160-167, 2005.

RODRIGUES, A. C. N.; ROCHA, J. V.; BELETTI, M. E. Análise computacional da compactação da cromatina de espermatozoides de galo. Arquivos Brasileiros de Medicina Veterinária e Zootecnia, Belo Horizonte, v. 61, n. 6, p. 1302-1307, 2009.

ROSA, A. P.; STEFANELLO, C.; FERRUFINO, R. Influência da retirada total ou parcial da crista sobre o status reprodutivo de machos avícolas tipo corte. Revista Portuguesa de Ciências Veterinárias, Lisboa, v. 107, n. 581-582, p. 63-68, 2012.

RUTZ, F.; ANCIUTTI, M. A.; XAVIER, E. G.; ROLL, V. F. B.; ROSSI, P. Avanços na fisiologia e desempenho reprodutivo de aves domésticas. Revista Brasileira de Reprodução Animal, Belo Horizonte, v. 31, n. 3, p. 307317, 2007.

SAS - STATISTICAL ANALYSIS SYSTEM. User's Guide. version 9. 4.ed. North Caroline, SAS Institute INC., 2002.

SHARPE，R. M.; MCKINNELL，C.; KIVLIN，C.; FISHER, J. S. Proliferation and functional maturation of Sertoli cells and their relevance to disorders of testes function in adulthood. Reproduction, London, v. 125, n. 6, p. 769-784, 2003.

SURAI, P. F. Natural antioxidants in avian nutrition and reproduction. In: (Ed.). Fatty acid composition and antioxidant protection of avian semen. Nottingham: Nottingham University Press, 2002. p. 391-435. Cap 7.

TYLER, N. C.; GOUS, R. M. The effect of constant photoperiod on testis weight and the use of comb area to predict testis weight in broiler breeder males. South African Society for Animal Science, Pretoria, v. 38, n. 2, p. 153-158, 2008.

VERSTEGEN, J.; IGUER-OUADA, M.; ONCLIN, K. Computer assisted semen analyzers in andrology research and veterinary practice. Theriogenology, London, v. 57, n. 1, p. 149-179, 2002.

WEIR, C. P.; ROBAIRE, B. Spermatozoa have decreased antioxidant enzymatic capacity and increased reactive oxygen species production during aging in the brown Norway rat. Journal of Andrology, Washington, v. 28, n. 2, p. 229-240, 2007.

YOUSEF, M. I.; ABDALLAH, G. A.; KAMEL, K. I. Effect of ascorbic acid and vitamin E supplementation on semen quality and biochemical parameters of male rabbits. Animal Reproduction Science, Amsterdam, v. 76, n. 1-2, p. 99-111, 2003. 